The Deportation Express 
A MERICAN CROSSROADS

Edited by Earl Lewis, George Lipsitz, George Sánchez, Dana Takagi, Laura Briggs, and Nikhil Pal Singh 


\title{
The Deportation Express
}

A HISTORY OF AMERICA THROUGH FORCED REMOVAL

\author{
Ethan Blue
}

\section{ㄸ}


University of California Press

Oakland, California

(C) 2021 by Ethan Blue

Library of Congress Cataloging-in-Publication Data

Names: Blue, Ethan, author.

Title: The deportation express : a history of America through forced removal / Ethan Blue.

Other titles: American crossroads ; 6r. Description: Oakland, California :

University of California Press, [202I] | Series: American crossroads ; 6I |

Includes bibliographical references and index.

Identifiers: LCCN 2020058518 | ISBN 9780520304444 (cloth) | ISBN 9780520973107 (epub)

Subjects: LCSH: Deportation-United States-History. | Imprisonment-

United States-History. | Immigrants-United States-Social conditions.

Classification: LCC JV6483.B59 2021 | DDC 364.6/8-dc23

LC record available at https://lccn.loc.gov/2020058518

Manufactured in the United States of America

$\begin{array}{llllllllll}30 & 29 & 28 & 27 & 26 & 25 & 24 & 23 & 22 & 21\end{array}$

$\begin{array}{llllllllll}\text { IO } & 9 & 8 & 7 & 6 & 5 & 4 & 3 & 2 & \text { I }\end{array}$ 
The publisher and the University of California Press Foundation gratefully acknowledge the generous support of the Peter Booth Wiley Endowment Fund in History. 
